\title{
Cease and Desist
}

Freedom of Expression ${ }^{\circledR}$ in the Age of Intellectual Property

Kembrew McLeod

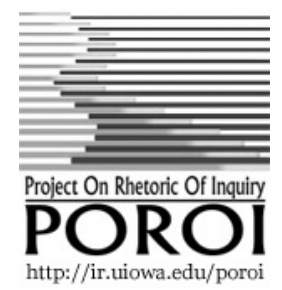

Poroi, 2, 2, November, 2003

1 The first shot fired in the intellectual property wars - the first one I heard, at least - happened during a skirmish between Island Records and Negativland, the sound-collage collective. In 1991, the corporate goliath took aim at the group's record - titled, simply, U2 - and blew it off the face of the earth. As a nerdy, motley crew of San Francisco Bay Area artists, weirdoes, and computer programmers, Negativland wasn't even a blip on the pop-culture radar, leaving it an unlikely target for a major lawsuit. So what would prompt one of the "Big Seven" record companies (now four, controlling 80\% of global record sales) to use its full legal and economic might against, essentially, the world's tiniest band? As you may have guessed from Negativland's album title, it made the mistake of sampling the music of U2: the crown jewel in Island Records' multi-platinum crown.

2 More troubling was that fragments of its music commingled with hilarious, gut-busting moments of tongue-tied obscenity by veteran DJ Casey Kasem. "This is American Top 40," says the congenial-sounding Kasem, "right here on the radio station you grew up with. Pubic Radio 138 ... OH, FUCK!" The amazing thing about this recording - which was duplicated and smuggled out of Kasem's studio by a disgruntled, abused staff member - is the surreal cognitive dissonance it provokes. The same voice that warmly announces innocuous hits by Phil Collins also spews mouth-foaming, foul-mouthed rants like: "That's the last fucking time! I want someone to use his FUCKING brains, and not come out of a record that's up-tempo every time I do a goddamn death dedication!"

3 Negativland's sound collage centered around a flubbed U2 introduction and "a long distance dedication" concerning the demise of a family's dog, Snuggles. "That's the letter U and the numeral 2," starts the host, innocently enough. "The four-man band features Adam Clayton on bass, Larry Mullin on drums, Dave Evans, nicknamed The Edge." Kasem suddenly grows agitated. "Wait, this is bullshit. Nobody cares! These people are from 
England, and WHO GIVES A SHIT? J ust a lot of wasted names that don't mean DIDDLEY SHIT!” To add insult to injury, Negativland also mixed in a speech by U2's lead singer, Bono, which made the self-important Nobel Peace Prize nominee sound pious and ridiculous. ${ }^{1}$

4 The record was released with little fanfare on SST Records, a small independent punk-rock label. But within four days of its release, Island Records and U2's song publisher, Warner-Chappel, came knocking to serve legal papers. ${ }^{2}$ Recognizing that it was a small fish compared to this oceanic multinational corporation, Negativland sent out a press release that stated, "Preferring retreat to total annihilation, Negativland and SST had no choice but to comply completely with these demands." 3 Even though Negativland had a strong fair-use argument, primarily based on parody, it didn't have the resources to fight a prolonged court battle. Instead it agreed to a very unfavorable settlement, a decision that haunts it to this day. Negativeland seems never really to have recovered.

5 "Companies like Island depend on this kind of economic inevitability to bully their way over all lesser forms of opposition," the group stated in a 1991 press release. "Thus, Island easily wipes us off the face of their earth purely on the basis of how much more money they can afford to waste than we can. We think there are issues to stand up for here, but Island can spend their way out of ever having to face them in a court of law."4 In a couple sentences, Negativeland sums up the heart of this essay: Backed by millions of dollars, intellectual property owners can wish away unflattering commentary by intimidating those who can't afford a lengthy court battle (which is most of us).

\section{Trademarking Freedom of Expression}

6 Negativland introduced two of the major influences on my life: media pranks and copyright law. The U2 v. Negativland lawsuit turned on a light bulb that still shines in my head. An undergrad term paper, a grad-school essay, a dissertation: after that, I was in over my head. The seedlings of my prank were planted in 1991, when I told one of my undergrad mentors, Dr. Bruce Busching, about my emerging interest in intellectual property law. I remember that we joked about trademarking the phrase "free speech" or "freedom of expression" or something like that. A few years later, I raised \$240 for the application fee. 
7 When I received the certificate from the PTO, I felt like a proud father whose baby has been delivered by the United States Postal Service rather than the stork. I wanted to light a cigar and announce my new offspring to the entire world. After I had exhausted every friend who would listen patiently to me, I needed to find another audience; and I knew just the way to get it: with a media prank. Taking a cue from Negativland, I learned early in life how easy it can be to manipulate the media into telling my strange little stories. (When I was an undergrad, I gained local and national media attention by attempting to change the J ames Madison University mascot to a three-eyed pig with antlers. A few years later, I sold my soul in a glass jar on eBay. Among other things...)

8 Pranks, for me, aren't the same as hoaxes. Hoaxes use deception to make someone or something look foolish, and nothing more. Media pranks, on the other hand, cook up a story or event to make a larger, satirical point. For instance, 1960s radicals Abbie Hoffman and J erry Rubin dumped hundreds of dollar bills from a balcony overlooking the New York Stock Exchange. This caused trading to stop as brokers grabbed at the money falling from the sky. Hoffman and Rubin invited reporters to cover the event, which was designed - ingeniously and hilariously - to peel back the blanket of respectability that hides the naked greed bubbling beneath the Stock Exchange.

9 Over the years, when people would ask me about my research focus, I could see the boredom slowly descend over their eyes as I told them, in my nerdy grad-school manner, "I'm interested in the intersections of intellectual property law, culture, and power ... yadda yadda yadda." But when I told them how I trademarked Freedom of Expression ${ }^{\circledR}$, their eyes would light up and they would laugh. Suddenly people would become interested in this esoteric topic, even when I started ranting about intellectual-property factoids such as how Time-Warner vehemently polices its copyright on "Happy Birthday to You." (I should be careful of what I write, or whom I criticize, because Factoid ${ }^{\circledR}$ is a registered trademark of DC Comics, a subsidiary of the... Time-Warner empire.)

10 After my book on Owning Culture: Authorship, Ownership and Intellectual Property Law came out in 2001, the publisher of a very smart magazine of cultural criticism - Stay Free! - contacted me. ${ }^{5}$ Carrie McLaren was putting together an art show named "Illegal Art: Freedom of Expression in the Corporate Age." (Being 
the good egg that I am, I didn't ask her to pay royalties for using my trademark.) She wanted to include my framed government certificate for Freedom of Expression ${ }^{\circledR}$ in an exhibit to feature art and ideas that push the envelope of intellectual property law. I was flattered to discover that the many great artists in the show included film director Todd Haynes and ... Negativland.

11 Serendipitously I was teaching at that time an undergrad course on intellectual-property law. One of my students, Abby, brought in a copy of an AT\&T ad from the Daily Iowan that used the slogan "Freedom of Expression" - WITHOUT MY PERMISSION - to lure college students into signing up for a long-distance plan. My class told me I should sue AT\&T. We all laughed. I said, "Sure," then I forgot about it for a couple months. But soon the media prankster gears began to turn in my head. I realized that the synergy of the art show, the publicity it was generating, and my own Freedom of Expression ${ }^{\circledR}$ project was too perfect not to exploit. I hired a lawyer in Iowa City, gave him my government documents and a copy of the ad, and he drafted a cease-and-desist letter addressed to AT\&T. This is just what it would have done to me if I had stepped on its trademarked toes.

12 Conspiring with the Chicago organizers of the Illegal Art show, the good folks at the lefty In These Times magazine, I used show's opening as a press conference to publicly announce my scheme. The New York Times broke the story and others picked it up. These included the U.S. government's overseas broadcasting arm, Voice of America, enabling me to air my criticisms of intellectualproperty law all the way to Afghanistan. Later in the year, my framed trademark certificate adorned the walls of the Artist's Gallery in the San Francisco Museum of Modern Art. Yet the most surreal moment came when a group of German artists and academics flew me to Berlin to lecture about these high-jinks. All in all, the freedom of expression ${ }^{\circledR}$ media prank was succeeding for me, because I finally had found a way to broadcast to millions including a few nutty Berliners - a critique of current intellectualproperty law that wouldn't normally get national or international attention. People like me, like us, don't usually have much of a voice in today's massive media conglomerates; and this prank let me turn up the volume, briefly, for something that I care about.

\section{What Is It That I Care About?}

13 The year 2003 was the moment the intellectual-property wars spilled into our living rooms. It was a surreal time to be writing a 
book about this formerly obscure topic because, week after week, the stakes seemed to get higher, the scenarios more bizarre. The high-water mark in the insanity came when Fox News sued Al Franken and his publisher, Penguin, for entitling his book Lies and the Lying Liars Who Tell Them: A Fair and Balanced Look at the Right.6 The veteran satirist used the Fox News slogan "Fair and Balanced," and the company claimed that this trespassed on its trademark. (Unlike Fox News, though, the registering of my trademark was intentionally ironical.)

14 By associating Al Franken's name with Fair and Balanced ${ }^{\circledR}$, the Fox lawyers argued, the book's title would "blur and tarnish" the good reputation of the Fox News trademark. The lawsuit described Franken as "increasingly unfunny." Franken responded by saying that he had trademarked "funny" and was considering a countersuit.7 Despite the earnest legal arguments of the Fox lawyers, who drew waves of laughter from the courtroom when they advocated their indefensible position, U.S. District J udge Denny Chin dismissed the injunction against the book. ${ }^{8}$ "There are hard cases and there are easy cases," Chin told Fox's lawyers. "This is an easy case in my view and wholly without merit, both factually and legally."9

15 Fortunately for Franken, Penguin is a major publishing house and was willing fight this legal battle for him. Most of us cannot tap such resources. J ust ask artist Tom Forsythe, who took satirical photographs of Barbie. (They weren't pornographic, if that's what you're thinking.) This prompted a trademark lawsuit from Mattel that cost Forsythe nearly a quarter million dollars in legal fees before a court ruled that his artwork is clearly satirical and doesn't cause consumer confusion.10 Most people - those who don't want to lose their shirts or their homes - usually back off after receiving a bullying cease-and-desist letter, giving a decided legal advantage to the few with huge amounts of money to spend on lawyer fees.

16 Although the Fox v. Franken case is funny, it's a disturbing reminder of how intellectual-property law is used increasingly to restrict the way we're allowed to comment on the media, to express ideas that copyright and trademark owners don't like. Current law severely restricts our freedom of expression ${ }^{\circledR}$. As culture becomes fenced off and privatized, it becomes all the more important for us to be able to comment on the images, ideas, and words that saturate our lives on a daily basis. The worry about lawsuits, expensive even when meritless, takes away the ability to criticize freely and creatively. That's what makes this first and foremost a 
free-speech issue. Unfortunately, many intellectual property owners and lawyers see it as an economic issue. Both positions make sense, I guess: it just depends on which we want our society to value more.

17 Unlike Fox v. Franken, not all legal decisions go the way of common sense. While writing this introduction, for example, I received an email from a frustrated Scott Smith. He is the president of BizStarz, and he figured I'd be interested in his story. His company, formerly EntrepreneurPR, was forced to change its name because a competing firm successfully trademarked the word entrepreneur. I kid you not. Entrepreneur Media, Inc. (EMI) secured broad control over the use of the word when U.S. District Court J udge Florence Marie-Cooper overturned a ruling by the Ninth Circuit Court of Appeals. Unsurprisingly EMI declared the ruling "a complete victory for our customers," though Scott Smith and other speakers of the English language probably see it differently.11 (Even the term semiotics, popular among pretentious professors like myself, was trademarked in 1984 by a marketing firm in Des Moines, Iowa. ${ }^{\mathbf{2}}$ )

18 The United States invaded Iraq in 2003. One day after the official start of hostilities, electronics giant Sony applied to register the trademark "Shock and Awe." The phrase was being used by the U.S. military to describe its bombing campaign, and the company intended to use it as the title of a new video game. Eventually Sony received such widespread criticism - especially beyond the United States, where Gulf War 2.0 has proven quite unpopular - that it dropped its trademark claim. That didn't stop a Texas company from registering "Shock and Awe" for its line of condoms, apparently aimed at men with issues of self-esteem.

19 A few days after the war began, Michael Moore accepted an Academy Award for his documentary on Bowling for Columbine with a controversial anti-war speech. But the Academy of Motion Picture Arts and Sciences denied Moore copyright permission when he tried to include his own speech as an extra on the DVD release of the documentary. This forced him to recite it word-forword for the DVD. Surely the Academy wasn't planning to sell copies of his speech, so the issue wasn't economic. The Academy was simply using copyright as a way to censor what it did not like.

20 Also in 2003, the Supreme Court upheld the Sonny Bono Copyright Term Extension Act, which lengthened copyright law by twenty years. ${ }^{13}$ I'll just call it the Bono Act, but its sarcastic name 
has become the Mickey Mouse Act, because Disney and other entertainment companies were instrumental in pushing this legislation through Congress. It would have been a significant year for the rodent: in 2003, the cartoon Steamboat Willie, the first appearance of Mickey, would have lost its copyright protection. The Bono Act also means songs like Time-Warner's "Happy Birthday to You" and Woody Guthrie's "This Land is Your Land" will remain private property for an additional twenty years. It is not hard to imagine this making the socialist folk singer roll in his grave.

21 If you've ever been to a restaurant chain and heard the servers sing an unfamiliar version of the birthday song, they're probably not breaking from the monotony of their job by being creative. It's more likely that their employee manual instructed them not to sing "Happy Birthday to You." Restaurants whose servers sing that song must buy a license from ASCAP, the organization that collects royalties for songwriters, and it's an expense most restaurant owners aren't willing or able to pay. Many chain restaurants don't allow the song to be sung on the premises, and other establishments such as ShowBiz Pizza Place and Bennigan's have their own versions of it to avoid costly licensing fees or potential lawsuits. ${ }^{14}$

22 If the point of copyright law is meant to encourage the creation of new books, songs, etc. - and according to the U.S. Constitution, that is its primary purpose - how does society benefit from such ridiculous constraints? What do we gain when one corporate entity owns the performance rights to a song that we've been singing since we were children, a song that our parents sang when they were kids, and - in some cases - a song our greatgrandparents likely sang at the turn of the last century? I understand how Time-Warner benefits. It makes millions of dollars a year from the royalties generated from television, film, and live performances.

23 Thanks to that 2003 Supreme Court ruling, the communications giant will continue to receive earnings from the song until 2030 or until, as is likely, Congress extends the copyright term even further. Whether we are talking about melodies, genes, public spaces, English words, or whatever, there's a rapidly accelerating push to pin down every imaginable thing as a piece of private property. Those economic values clash with the values of free speech, creativity, and shared resources. These expressive values aren't hippy-drippy dreams. Rather they're the very reasons why 
the framers of the U.S. Constitution argued for the existence of copyright and patent law: so that society would benefit from a rich culture accessible to all.

\section{Our Privatized World}

24 My own little freedom of expression ${ }^{\circledR}$ prank wasn't half as funny or ironic or troubling - as the time when a performance art troupe from Wisconsin was successfully prosecuted for (among other things) passing out copies of the First Amendment in a shopping mall. The problem was the troupe distributed this founding document of American free speech against the management's wishes. ${ }^{15}$ The prank and the conviction are funny at first, until they remind us that we live in a country where property rights trump human rights virtually every time. Still the situation's humorous irony is what keeps me from jumping out windows when I think about it - or getting angry enough to "apply the critique of the brick."

25 Even though I hadn't yet heard the First-Amendment-in-theshopping-mall story when I trademarked freedom of expression ${ }^{\circledR}$, I was tapping into the same impulse that drove the performance art troupe to hand out flyers. Those people in Wisconsin have been concerned about the privatization of public space, and they have responded by testing the limits of legal system. I, in turn, have been worried about the privatization of our culture. A couple decades ago, those performance artists fought the law, and the law won. Thus far, I've prevailed because, well, the federal government has bestowed upon me the status of property owner: in this case, intellectual-property owner. Lucky me.

26 Growing in influence over the past quarter-century is an ideology that asserts that ownership rights should trounce everything else, including the right to free speech: a sort of property ownership über alles. There's a direct parallel between the way property laws and intellectual property laws are currently being used to erect fences around public space - both physical and cultural. In doing so, these property owners use the law to shape and exclude discourses that are necessary to build popular fronts of resistance that can do battle with the dominant culture.

\section{The Mall as Metaphor}

27 Let me dwell for a moment on the shopping mall. It is a metaphor 
for what has happened to cultural and economic life in America, a symptom and a cause of the erosion of our freedom of expression ${ }^{\circledR}$. As you know, there used to be things called downtowns.

Downtown areas still exist in a handful of cities throughout the U.S., but they are anomalies in a landscape cluttered with suburban shopping malls and strip malls. This is too bad, because it was the downtown where people used to gather to mix with other community members and occasionally participate in social change by exercising their First Amendment rights of free assembly and free speech. The replacement of the downtown as the center of social and economic life in America completed the shift from the city to the suburbs, with the vast changes that brought. The downtown belonged to everyone - in theory, at least, and sometimes in practice. But most state courts and legislatures have claimed that the free speech rights we are guaranteed in the public places downtown within cities do not extend to similar private properties like malls.

28 This makes it possible for someone to be arrested for wearing an objectionable t-shirt during the buildup to Gulf War 2.0. On March 3, 2003, a lawyer named Steve Downs was arrested for trespassing at the Crossgates Mall in Albany, NY because he refused to remove a t-shirt that declared "Peace on Earth" and "Give Peace a Chance." (He had purchased the offending t-shirt, by the way, at the mall.) Mall officials claimed that the t-shirt violated its policy of banning clothes that are "disruptive." The mall's management said that it "is committed to maintaining the mall as a family-friendly facility that provides a secure and enjoyable experience. ... While Crossgates Mall is perceived by some to be a public place, it is privately owned."16

29 Even the things that have traditionally been called public squares are being branded and privatized. In 1997, anti-tobacco protesters were forcibly removed during a jazz festival from Nathan Phillips Square - in front of Toronto's City Hall. The festival was sponsored by a tobacco company; and during the week of the festival, this public space essentially became the private property of the company, which exercised its policing power by kicking out dissenters. That same year, anti-tobacco protesters were removed from their own campus in Toronto during the du Maurier Tennis Open, because the students objected to the fact that it was sponsored by a tobacco giant. ${ }^{17}$ Throughout North America, business districts are being turned into little more than outdoor malls with real cops, rather than rent-a-cops, policing the area. 
30 When it hosted the 2002 Winter Olympics, Salt Lake City set up "free speech zones" that were carefully placed in the city's least populated areas, severely limiting the impact of so-called free speech. (The US Olympic Committee itself has used its trademarked property ideologically, by allowing the existence of the Special Olympics but not the Gay Olympics. After a lawsuit, competitors get the Gay Games.) In Seattle, during the 1999 World Trade Organization protests, similar spaces were demarcated for protest, but other areas were fiercely protected by the state-policing apparatus. When people can only express themselves legally in certain "free speech zones," the question becomes: what is the rest of the city called? I'm reminded of an old Guerilla Girls' poster, the one that asks:

If February is Black History Month and March is Women's History Month, what happens the rest of the year? Discrimination. ${ }^{18}$

31 Intellectual property and physical property intersect when a disturbing number of companies go to extreme lengths to control visual reproductions of their buildings. The director of publishing at FPG International, one of the largest stock-photo agencies, claims that this increasingly affects the firm's business. If someone wants to use an existing photograph of a building in FPG's stock-photo library, FPG often informs the customer that certain property owners require special releases or, in some cases, "licensing fees." (Imagine having to pay to "sample" a building). "What's happened," says Rebecca Taylor, "is we've had to establish certain business practices based on the harassment factor. It's become part of doing business - it's just one more thing we have to worry about." FPG tells photographers in the midst of their work that certain buildings aren't worth shooting or can only be imaged for editorial, "fair use" purposes. "Whether these property owners really have these trademark rights is questionable," says Taylor, "but we've decided it's an issue that's not worth fighting over."19 Among the Manhattan property owners that aggressively protect their trademarks are the New York Stock Exchange, the Chrysler Building, Rockefeller Center and even the New York Public Library. 20

32 Federal law protects trademarks from being portrayed in an "unwholesome or unsavory context." Companies can and do wield trademark law as a weapon of censorship, and courts sometimes frame their decisions in terms of physical property. For instance, 
the Manitoba Court of Appeal ruled that striking Safeway workers could not appropriate the Safeway trademark in their union

literature. The Court stated that "there is no right under the guise of free speech to take or use what does not belong to [you]."21

Similarly, when an environmental group used a caricature of the Reddy Kilowatt trademark in literature that was critical of the electric utility industry, the company responded by filing an injunction for the unauthorized use of their mark. ${ }^{22}$ This injunction was upheld by the U.S. District Court for the District of Columbia, which ruled, essentially, that you cannot use a trademarked property to express yourself - it constitutes a type of "trespassing."

33 Not everyone in the U.S. and abroad is allowing our public and cultural space to be colonized without a fight. Citizens were up in arms when, in 2003, Vienna's Karlsplatz - a public square of historical import - displayed the "Nike Infobox." There was a slick walk-in container with two semi-transparent floors sporting signs that declared to passersby: "This square will soon be called Nikeplatz. Come inside to find out more." During the month-long time of the Infobox in Karlsplatz, ending on October 28, 2003, thousands of brochures were distributed throughout the city that laid out plans for the "Nike Ground" campaign. "Nike is introducing its legendary brand into squares, streets, parks and boulevards," proclaimed the propaganda found inside the Nike Infobox. "Nikesquare, Nike street, Piazzanike, Plazanike or Nikestrasse will appear in major world capitals over the coming years!"

34 The newly introduced Nikeground.com Web site displayed the slogan: "You want to wear it, why shouldn't cities wear it too?"23 If that weren't enough to rile the average Viennese resident, the Infobox went on to promise that a $36 \times 18$ meter monument in the shape of Nike's "Swoosh" logo would be placed in the center of Karlsplatz, soon to be called Nikeplatz. People freaked out, and soon thousands of emails and handwritten letters descended on Austrian newspapers and city governments. The incident turned out to be a clever prank engineered by a band of media artists collectively known as 0100101110101101.ORG. The intent was to create a collective hallucination in which Vienna itself was the theater. ${ }^{24}$ (As Shakespeare famously quipped, all the world's a stage.)

35 The larger purpose was to provoke conversation and debate; and judging by the intense negative feedback generated, the prank 
succeeded. It also succeeded in provoking a lawsuit from Nike, which objected to the unauthorized use of its trademarked name and logo. But Nike lost the first round on a technicality. The Commercial Court of Vienna ruled that, because the company is based in the U.S., it needed to pay a deposit covering the cost of litigation in case the pranksters won. Because Nike International didn't do this, the Nike Ground display was allowed to remain for the planned month-long period, which came before Nike could file another injunction. Although the media collective won on a technicality, even such a small victory is heartening for activists and artists who feel compelled to trespass on the privately owned signifiers of corporate culture.

36 Like other anti-globalization and anti-sweatshop activists, the collective used the lumbering cultural weight of the Swoosh against Nike: like Derridian judo masters who trip up their philosophical opponents. (In Derrida's case, this has meant turning the heft of Western philosophy on itself, making it fall on its face, mocking it). These artists and activists echo the tactics of 1960s Situationists, who détourned the intellectual properties of the dominant culture to subvert intended meanings by placing objects in new contexts. 0100101110101101.ORG tacitly acknowledged this when its spokesperson Ted Pikul stated, "Nike is a perfect subject for a work of art. The Swoosh is probably the most viewable brand on earth, more than any political or religious symbol. Now these giants are loosing control over their own brands, which in the hands of pop culture are turning into boomerangs." 25 Intentionally or not, his comment conjures the image of an arty Charles Atlas or Charlie's Angel who wrests control of the Swoosh with both hands then bends it into a boomerang that will come back to whack Nike CEO Phil Knight in the head.

\section{Intellectual Property v. Free Speech and Democracy}

37 If you read the headline "File Trading Students Out To Save Democracy," you chuckle. Right? But it's true. Late in 2003, a company named Diebold has been sending colleges and their students a series of cease-and-desist letters. Do the Diebold letters target MP3 files circulating through peer-to-peer networks and on the Web? No, Diebold makes voting machines. The headlined scenario unfolded when a handful of student voting activists posted 15,000 copyrighted documents on their Web sites. This 
prompted a familiar sequence of events: the company sent threatening letters to colleges, which in turn removed the objectionable content from their networks, which made the students mad.

38 What are the documents? They are thousands of internal memos, emails, and discussion list postings that paint a behind-the-scenes picture of Diebold that isn't flattering, to say the least. In these documents are myriad statements that suggest the company's electronic voting machines contain many security problems and bugs in the software, as well as last-minute changes that are illegal after elections authorities certify software for an election. ${ }^{26}$ Among the most disturbing is the following missive sent by a frantic employee about the company's machines during the 2000 Presidential election:

I need some answers! Our department is being audited by the County. I have been waiting for someone to give me an explanation as to why Precinct 216 gave $\mathrm{Al}$ Gore a minus 16022 when it was uploaded. Will someone please explain this so that I have the information to give the auditor instead of standing here "looking dumb." I would appreciate an explanation on why the memory cards start giving check sum messages. We had this happen in several precincts and one of these precincts managed to get her memory card out of election mode and then back in it, continued to read ballots, not realizing that the $300+$ ballots she had read earlier were no longer stored in her memory card. Needless to say when we did our hand count this was discovered.

Any explantations [this is email] you all can give me will be greatly appreciated.

Thanks bunches, Lana [Hires] ${ }^{27}$

Diebold claims that it owns the copyright to these memos, which may in fact be true. But these vote-and-boat-rocking students argue that their posting is a "fair use" of the company's materials, because it's in the context of news reporting and criticism, which is also the case. What is most obvious is that Diebold was attempting to use copyright law to censor what it doesn't like, and nothing more. More specifically, this is yet another disturbing way that the Digital Millennium Copyright Act gives copyright owners even 
more power to erase dissent. The DMCA stipulates that Internet Service Providers can only be immune from prosecution if they immediately comply with "take down" requests by copyright owners. Even if the copyrighted materials appear in a "fair use" context, the DMCA is written in a way that makes it hard for freedom of expression ${ }^{\circledR}$ to prosper online.

39 This is what happens when more and more things fall under the rubric of private property, making it possible for a Diebold spokesman to say with a straight face, "We reserve the right to protect that which we feel is proprietary."28 In the midst of the controversy, a Swarthmore College sophomore astutely observed, "If I were Diebold I wouldn't claim copyright protection; I'd claim I hadn't written the memos."29 Colleges like Swarthmore, in Morristown, NJ , caved to Diebold's cease-and-desist letters, although they at least have given the students moral support and legal advice. Yet Diebold's attempt to put out this digital fire only made it grow. The documents multiplied exponentially as computer-savvy voting activists linked to other Web sites and distributed them across peer-to-peer file-sharing networks.

40 A friend of mine, NYU copyright scholar Siva Vaidhyanathan, points out that this episode highlights the social function of filetrading and how it has ramifications far beyond downloading a Nirvana song. He says, "We're so focused on the micro viewwhether EMI is going to make a buck next year - but there is so much more at stake in our battle to control the flows of information." This includes issues that go to the heart of democracy and freedom of expression ${ }^{\circledR}$. Yes, the dissemination of those copyrighted memos might hurt the future sales of voting machines, which is obviously why Diebold attempted to suppress this information. But first, copyright law was intended to promote the proliferation of knowledge, not stifle it; and second, of all the instances when profits shouldn't matter, it's when democracy itself is on the line.

41 There's a lot of money to be made in e-voting - billions, in fact. After the 2000 elections, hanging chads, butterfly ballots, and all, President Bush signed the Help America Vote Act (HAVA). It allocates $\$ 3.9$ billion to states that adopt electronic polling machines. That's a lot of money to be divided largely between the three major suppliers of electronic voting machines in the U.S.: Diebold, Sequoia, and Election Systems and Software. Many experts have noted the obvious problem with relying purely on electronically counted elections: there is no printed record of the 
votes for a fall-back when the machines fail or are misused. ${ }^{30}$ When viewing the elections returns, we are simply expected to take the company's word - despite the fact that Diebold's own machines, for instance, registered negative 16,022 votes for $\mathrm{Al}$ Gore in one Florida district. ${ }^{31}$

42 Even more troubling - and another reason that the privatized election business should be more transparent - is the fact that Diebold is a heavy supporter of Republicans. ${ }^{32}$ In the two years after 2000, the company gave $\$ 195,000$ to the Republican Party. Its CEO, Walden W. O'Dell, even wrote to campaign contributors that he is "committed to helping Ohio deliver its electoral votes to the president next year." 33 I'm sure he did not literally mean that he would use his company to tamper with voting machines to illegally swing the Ohio elections Bush's way. Nevertheless these considerations make me uneasy, and the fact that the company announced that O'Dell would take a lower political profile doesn't make me feel any better.

43 Although these actions reek with conflict of interest, it would be far less troublesome if there were a verifiable paper count to back up the results of these machines. But there probably won't be such a thing in the near future, for two reasons. First, HAVA doesn't require paper printouts of voting results. Second, Penelope Bonsall, the director of the Federal Election Commission's Office of Election Administration, is on record as saying, "If you have electronic machinery, why would you ever do a paper count?" Her office sets the guidelines for the voting process. Her apparently blind faith in e-voting is enough to induce nightmares: "If you have to deal with pieces of paper I think that you're defeating your purpose."34 Her statement not only defies common sense, it's simply not true.

44 The file-trading activists' electronic act civil disobedience is only part of the story. The larger concern is how the nuts and bolts of the democratic voting process are being privatized through patent, copyright, and trade-secrecy law. Incredibly states have agreed to sign strict trade-secrecy contracts that make it not only difficult but illegal to have the machines examined by a third party. Moreover the company's software is made inaccessible through copyright and patent laws. This means that there is no legal way for citizens to look for security flaws or other errors in the electronic-voting programs and machines. ${ }^{35}$ A Georgia woman claimed she could crack Diebold's system in minutes, and the Georgia Secretary of State Cathy Cox accepted that challenge. But 
the woman had to back down after being informed it was a criminal offense to be given the code. This is another unsettling example of how the ethos of privatization has crept into virtually every area of our civil society, from education to elections, with potentially disastrous results.

\section{Commerce and Copyright}

45 Some may say that the scenarios in this essay are unfortunate but necessary consequences of making sure that copyrighted goods are secure, because property should be protected. It's understandable that individuals and companies seek protection for their creations, but the idea that copyright is a form of private property is neither natural nor inherent in most conceptions of private property. For most of our history, the idea would have defied common sense. Yes, copyright is a form of legal protection; but only recently has copyright been reconceived as personal property, rather than a cultural good that is granted temporary legal protection. This protection, according to the U.S. Constitution, doesn't give the author total control over how it is distributed or consumed.

46 For nearly two centuries after the Constitution was adopted, U.S. courts interpreted copyright as something that encouraged authors to create new cultural goods to benefit and eventually belong to our society. It may seem to be common sense that copyrighted goods are just like a house that you build and pass down to your children, and I understand why many people buy this argument. But it's when things seem the most obvious that ideology is at work, shaping the way we see the world. And that's when we should question our assumptions. The godfather of cultural studies, Stuart Hall, tells us, "When people say to you, 'Of course that's so, isn't it?' that 'of course' is the most ideological moment, because that's the moment at which you're least aware that you are using a particular ideological framework."36

47 J essica Litman and many other legal scholars have demonstrated that framers of the U.S. Constitution believed there needed to be a system that encouraged people to create. But they clearly argued that this should occur by providing limited protections for their works. Thomas J efferson argued, “ideas should freely spread from one to another over the globe." 37 J efferson's italics tell us that he felt strongly about this. J efferson and his contemporaries believed the uninhibited spread of ideas, information, and culture essential to a thriving democracy. Even though he was concerned that intellectual-property law could block the free flow of 
knowledge, J efferson didn't argue against the existence of copyright. To the contrary, he stated, "Society may give an exclusive right to the profits arising from them, as an encouragement to men to pursue ideas which may produce utility."

48 Those who contributed to drafting the U.S. Constitution, most notably J ames Madison, agreed that it should cover copyright and patent law. The list submitted by Madison included three powers of the federal government: "To secure to literary authors their copyrights for a limited time. To establish a university. To encourage, by premiums and provisions, the advancement of useful knowledge and discoveries." Significantly the Constitution's framers took care to include the phrase "limited times" in the language concerning copyright and patent law so there would be no permanent monopolies. ${ }^{38}$ Of utmost importance were the promotion of learning and the dissemination of culture; of secondary importance was creating a statutory protection for the author.

49 But today's overzealous copyright bozos don't understand, or just don't care, that copyright was intended to balance the needs of the owner and the good of society, with society always coming first. For instance, the movie studios fought in the 1980s against the introduction of the VCR, claiming that this newfangled machine would destroy their industry because people would no longer pay to see movies. In 1984, the studios took their battle all the way to the Supreme Court and, fortunately, the high court took the side of the public's best interest. In the this case, Supreme Court J ustice Stevens made clear that the monopoly power of copyright was designed first and foremost to benefit society.

50 Copyright's purpose, he argued in the majority opinion, is not to provide a special private benefit. "Rather," wrote Stevens, "the limited grant is a means by which an important public purpose may be achieved. ... It is intended to motivate the creative activity of authors and inventors by the provision of a special reward, and to allow the public access to the products of their genius after the limited period of exclusive control has expired. The copyright law, like the patent statutes, makes reward to the owner a secondary consideration" [emphasis mine]. ${ }^{39}$

51 Congressional testimony, legal briefs, law articles, and books from twenty years ago and beyond suggest a widespread assumption that balancing author interests and public interests is the guiding principle of the law. "Copyright was a bargain between the public 
and the author," explains J essica Litman, "whereby the public bribed the author to create new works in return for limited commercial control over the new expression the author brought to her works." Before 1976, "limited times" meant "only" 56 years: after that, copyrighted works went into the public domain. ${ }^{\mathbf{4 0}}$

52 Copyright was designed to be porous; it was meant to be full of holes to provide some freedom and flexibility to the public. This would enable the public to enjoy, consume, and reuse works in ways that didn't infringe on the author's rights. Copyright was not intended to give authors complete control over their works. The underlying premise of this theory of copyright is to guarantee that neither the author nor the public would reap a lion's share of profits from the creation of new works. The proceeds would be shared so as to encourage the promiscuous creation of new works. But by the early 1980s, the "balanced bargain" rhetoric of copyright began to change, as advocates for copyright holders began to reconceive copyright's purpose by drawing from an economic analysis of the law. ${ }^{41}$

53 The reconception made sense at a time when - as is still true today - information and media were large and growing parts of the global economy. For most corporations, and the politicians whose campaign coffers they filled, this change in perspective was a very practical matter. There was no need for any of socialist-sounding nonsense about public goods, even if it did originate with protocapitalists like J ames Madison and Thomas J efferson. Over the last quarter-century, accordingly, the dominant metaphor for copyright changed from a shared, balanced model to one of private property that needs to be protected - by any means necessary. Sadly this is doing more to inhibit creativity and freedom of expression ${ }^{\circledR}$ than to encourage it.

(c) Kembrew McLeod, 2003.

\section{Notes}

1 See Negativland, U2, Los Angeles, SST, CD, 1991.

2 See R. Harrington, "The saga of Negativland's Sued Success," Washington Post, May 17, 1995, p. C7.

3 Negativland, "The Case from Our Side," RetroFuturism, March, 1992, pp. 1750-1757. 
$4 \quad$ Ibid., p. 1752.

5 See Kembrew McLeod, Owning Culture: Authorship, Ownership and Intellectual Property Law, New York, Peter Lang, 2001.

6 See Al Franken, Lies and the Lying Liars Who Tell Them: A Fair and Balanced Look at the Right, New York, Penguin Books, 2003.

7 S. Saulny, "To Fox, Fair and Balanced Doesn't Describe Al Franken," New York Times, August 12, 2003, http:/ / www. nytimes.com/2003/08/ 12/ nyregion/ 12FRAN. html?ex= 1061697600\&en $=59202 a 68 f 0 b f e e 43 \& e \mathrm{i}=5070$.

8 See S. Saulny, "In Courtroom, Laughter at Fox and a Victory for Al Franken," New York Times, August 23, 2003, http:/ / www.nytimes.com/2003/ 08/23/ nyregion/ 23FRAN. html?ex=1062696590\&ei=1\&en=b6ba52773097f054.

9 P. Hurtado, "Fox Blocked in Case against Al Franken's Book," Newsday, August 22, 2003, http:/ / www.nynewsday. com/ nycfran0823,0,1365110.story?coll=nyc-topheadlines-left.

10 See C. Seim, "Freedom of Expression Is No J oke - or Is It?" Medill News Service, 2003, http://journalism.medill. northwestern.edu/ docket/ 02-0428expression.html.

11 "Round Three in Trademark Suit Goes to EMI," MicroEntertprise J ournal, J uly 7, 2003, http:/ / www. microenterprisejournal.com/articles/legal/20030707.html.

12 See R. Coombe, The Cultural Life of Intellectual Properties: Authorship, Appropriation and the Law, Durham, NC, Duke University Press, 1998.

13 See S. Breyer, Eric Eldred, et al., Petitioners v. J ohn D. Ashcroft, Attorney General. Supreme Court of the United States, No. 01-618, 2003.

14 See E. Hayes, “Happy Birthday to You Tune Can't Copyright Good Memories," Orlando Sentinel Tribune, April 10, 1993, p. E1; S. Shepard, "Name That Tune," Memphis Business J ournal, January 6, 1992, p. 3.

15 See Madison J oint Venture v. Robert W. Major and Nu 
Parable, 139 Wis. 2d 492, 1987.

16 D. Chambers, "Activists Protest Mall after Arrest of a Man Wearing Peace T-Shirt," Newsday, March 5, 2003, http:/ / www.newsday.com/news/local/ wire/ ny-bc-ny--mall activists0305mar05,0,7316106.story?coll= ny-ap-regional-wire.

17 See M. Marqusee, "Sport as Apocalypse," Frontline, August 518, 2000, http:/ / www.flonnet.com/ fl1716/ 17161100. htm.

18 Guerrilla Girls, Confession of the Guerrilla Girls, New York, HarperCollins, 1995.

19 J . LiPetri, "Owners Stretch Trademark Protection to Protect Buildings, Trees," Micro Publishing News, 1999, http:/ / www.micropubnews.com/ pages/ issues/ 1999/899 trademark_mpn.shtml.

20 See Ibid.

21 Coombe, The Cultural Life of Intellectual Properties.

22 See Ibid.

23 Nikeground, 2003, http:// www.nikeground.com.

24 See 0100101110101101.ORG, "Nike Buys Streets and Squares," Press Release, October 10, 2003.

25 0100101110101101.ORG, "Nike Scores Own Goal," Press Release, October 28, 2003.

26 See J . Schwartz, "File Sharing Pits Copyright against Free Speech," New York Times, November 3, 2003, http:/ / www.nytimes.com/ 2003/ 11/ 03/ business/media/ 03secure.html.

27 A. Orlowski, "E-voting Vendor Sued for DMCA Takedown," The Register, November, 11, 2003, http:// www. theregister.co.uk/ content/ 6/ 33750.html.

28 Ibid.

29 K. Zetter, "Students Fight E-vote Firm," Wired News, October 21, 2003, http:/ / www.wired.com/ news/ print/ 0,1294,60927,00.html. 
30 See M. Ezzard, “Goergias Vote System a Keeper," Atlanta J ournal-Constitution, October 7, 2003, p. 15A. [Online] Available: Lexis-Nexis.

31 See Orlowski, "E-voting Vendor Sued for DMCA Takedown."

32 See D. McCullagh, "Students Buck DMCA Threat," CNet News.com, November 3, 2003, http:// news.com.com/ 21021028_3-5101623.html.

33 K. Ervin, "Elections Chief Tightens Vote Security," Seattle Times, September 25, 2003, Lexis-Nexis.

34 S. Lubell, "To Register Doubts, Press Here," New York Times, May 15, 2003, p. G1, Lexis-Nexis.

35 See A. Gumbel, "All the President's Votes?" The Independent [London], October 14, 2003, pp. 2-4, Lexis-Nexis.

36 S. Hall, "The Narrative Construction of Reality: An Interview with Stuart Hall," Southern Review, 17, 1984, p. 8.

37 D. Post, "His Napster's Voice," Copy Fights: The Future of Intellectual Property in the Information Age, A. Thierer and C. W. Crews, J r., eds., Washington, DC, Cato Institute, 2002, pp. 107124.

38 See L. R. Patterson, Copyright in Historical Perspective, Nashville, TN, Vanderbilt University Press, 1968.

39 Sony Corporation of America v. Universal City Studios, Inc., 464 U.S. 417, 429, rehearing denied, 465 U.S. 1112, 1984.

40 See J . Litman, Digital Copyright, Amherst, NY, Prometheus Books, 2001, p. 78.

41 See Ibid. 